\title{
Therapeutic Strategies for Targeting Ovarian Cancer Stem Cells
}

\author{
Wookyeom Yang ${ }^{1}$, Dasol Kim ${ }^{2}$, Dae Kyoung Kim ${ }^{2}$, Kyung Un Choi ${ }^{3}$, Dong Soo Suh ${ }^{4}$ and Jae Ho Kim ${ }^{2, *}$ \\ 1 Convergence Stem Cell Research Center, Pusan National University, Yangsan 50612, Gyeongsangnam-do, \\ Korea; wookyeom@pusan.ac.kr \\ 2 Department of Physiology, School of Medicine, Pusan National University, Yangsan 50612, \\ Gyeongsangnam-do, Korea; dasolk95@naver.com (D.K.); kyumkiki@gmail.com (D.K.K.) \\ 3 Department of Pathology, Pusan National University Hospital, Busan 49241, Korea; kuchoi@pusan.ac.kr \\ 4 Department of Obstetrics and Gynecology, Pusan National University Hospital, Busan 49241, Korea; \\ dssuh@pusan.ac.kr \\ * Correspondence: jhkimst@pusan.ac.kr; Tel.: +82-51-510-8073
}

Citation: Yang, W.; Kim, D.; Kim, D.K.; Choi, K.U.; Suh, D.S.; Kim, J.H. Therapeutic Strategies for Targeting Ovarian Cancer Stem Cells. Int. J Mol. Sci. 2021, 22, 5059. https:// doi.org/10.3390/ijms22105059

Academic Editor: Julhash U. Kazi

Received: 30 March 2021

Accepted: 7 May 2021

Published: 11 May 2021

Publisher's Note: MDPI stays neutral with regard to jurisdictional claims in published maps and institutional affiliations.

Copyright: (c) 2021 by the authors. Licensee MDPI, Basel, Switzerland. This article is an open access article distributed under the terms and conditions of the Creative Commons Attribution (CC BY) license (https:// creativecommons.org/licenses/by/ $4.0 /)$.

\begin{abstract}
Ovarian cancer is a fatal gynecological malignancy. Although first-line chemotherapy and surgical operation are effective treatments for ovarian cancer, its clinical management remains a challenge owing to intrinsic or acquired drug resistance and relapse at local or distal lesions. Cancer stem cells (CSCs) are a small subpopulation of cells inside tumor tissues, and they can self-renew and differentiate. CSCs are responsible for the cancer malignancy involved in relapses as well as resistance to chemotherapy and radiation. These malignant properties of CSCs are regulated by cell surface receptors and intracellular pluripotency-associated factors triggered by internal or external stimuli from the tumor microenvironment. The malignancy of CSCs can be attenuated by individual or combined restraining of cell surface receptors and intracellular pluripotency-associated factors. Therefore, targeted therapy against CSCs is a feasible therapeutic tool against ovarian cancer. In this paper, we review the prominent roles of cell surface receptors and intracellular pluripotencyassociated factors in mediating the stemness and malignancy of ovarian CSCs.
\end{abstract}

Keywords: cancer stem cells; ovarian cancer; chemoreistance; stemess

\section{Introduction}

Ovarian cancer has the highest mortality rate among gynecological cancers. The World Cancer Report of the International Agency for Research on Cancer stated that 295,414 women were diagnosed with ovarian cancer in 2018 [1]. Diagnosis at an early stage has numerous benefits such as a longer survival rate; however, $80 \%$ of ovarian cancer patients are diagnosed at an advanced stage (III or IV) because they exhibit no symptoms in the early stages, following which the tumor disseminates to the peritoneal cavity [2-4]. Ovarian cancer has high heterogeneity, which is generated by various factors, including different histopathological properties, origin, clinical evolution, response to treatment, and genomic alteration, and can be divided into nine subtypes: serous, endometrioid, clear cell, mucinous, Brenner tumor, transitional cell, squamous cell, mixed epithelial, and undifferentiated [5]. Standard ovarian cancer treatment comprises first-line chemotherapy with a carboplatin-paclitaxel regimen and surgical debulking $[4,6]$. Although this regimen is initially effective, recurrence is persistent owing to intrinsic or acquired chemoresistance $[7,8]$. Most ovarian cancer patients suffer at least one relapse within 12 to 18 months $[9,10]$ owing to chemoresistance and metastasis $[3,11]$; hence, $70 \%$ of these patients die within five years $[1,4,9]$. Therefore, ovarian cancer treatment urgently needs to address challenges such as recurrence, chemoresistance, and metastasis.

Cancer stem cells (CSCs) are highly tumorigenic as tumor-initiating cells and possess the ability to self-renew, similar to normal stem cells $[12,13]$. Although CSCs are a rare population of tumor cells depending on the tumor type and stage [1], they are responsible for drug resistance, recurrence, and metastasis in response to tumor microenvironmental or non-microenvironmental stimuli [14-17]. Despite contradictory findings, the upregulated 
CSC pathway is responsible for the poor outcomes of many aggressive tumors [18]. CSCrelated cellular markers comprise cell surface and intracellular markers, which are closely connected via a complicated pathway that interplays with the tumor microenvironment. Many reports suggest that the individual or combined inhibition of CSC marker expression or activity effectively diminishes the growth and dissemination properties of CSCs both in vitro and in vivo $[19,20]$.

After CSCs were first found in ovarian cancer patient ascites [21], many studies have investigated the correlation between CSCs and ovarian cancer. Accumulating evidence indicates that the elimination of CSCs is required to inhibit ovarian cancer growth and frequent relapse $[19,20]$. Many studies have shown that there are stem-like epithelial cells in the ovarian surface [22] and fallopian tube epithelium [23]. Stem cells have been identified in the coelomic epithelium of mouse ovaries [24] and in a transitional region known as the hilum [25]. Although there is some evidence to the contrary, ovarian cancer is considered to originate from both these tissues $[20,26]$. Moreover, stem cell factors increase sphere formation and tumor transformation potential by inactivating TP53 and $\mathrm{Rb} 1$ via mutations; two tumor-suppressor genes are frequently mutated in high-grade serous ovarian cancer [27]. Stem cells play a crucial role in maintaining normal tissues, but they may be a double-edged sword because dysregulation and transformation through the mutation of tumor suppressors can cause cancer [28] (Figure 1). In this paper, we review potential therapeutic or diagnostic biomarkers for CSCs and discuss recent studies on approaches for targeting ovarian CSCs. 
A.

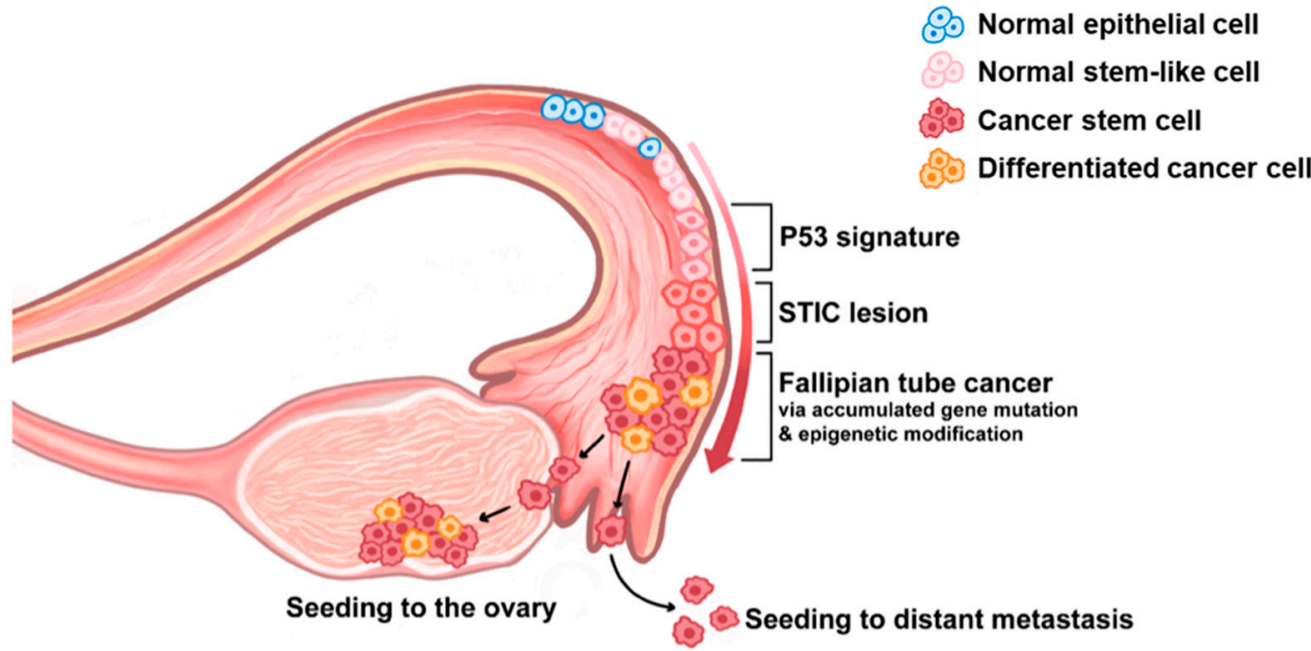

B.

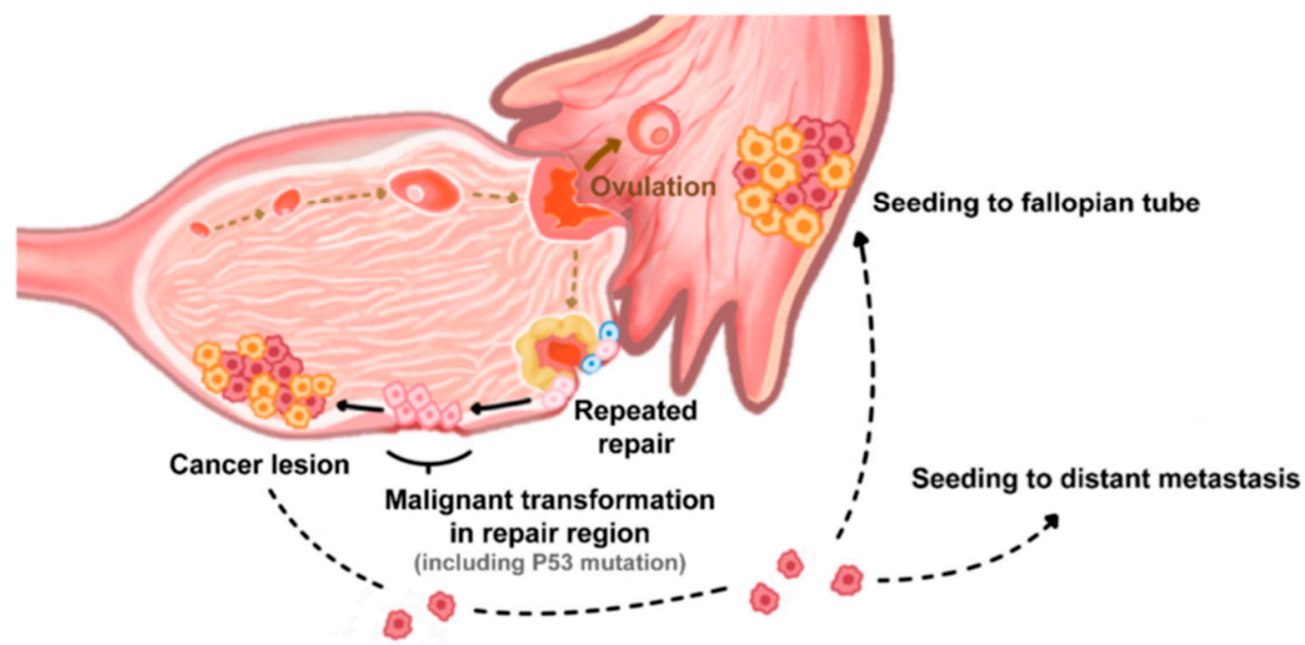

Figure 1. Origin and initiation of high-grade serous ovarian cancer. High-grade serous ovarian cancer originates from the fallopian tube (A) and surface epithelia (B). Both normal epithelia (blue cells) have a small subpopulation of stem-like cells (Pink cells), which express ALDH, CD117, CD133, CD24, and CD44. They exhibit stem cell properties, such as self-renewal and multi-differentiation potential. (A) The stem-like cells in the fallopian tube epithelium acquire p53 mutations owing to uncertain reasons. Then, they expand into serous tubal intraepithelial carcinomas (STICs), transform into fallopian tube cancer, and migrate to seed the ovarian epithelium or distant metastasis. (B) In the case of origin from the ovary surface, most researchers believe that the repetitive damages on the ovary surface during ovulation and repair cause accumulated mutations and p53 mutations in the stem-like cells of the ovarian surface epithelium.

\section{Cell Surface Markers of Ovarian CSCs}

\section{1. $C D 44$}

CD44 is a surface transmembrane glycoprotein that acts as a receptor, participating in various physiological processes such as cell-cell interaction, cell migration, and cell-matrix adhesion [29]. CD44 is one of the most common CSC markers, which is used individually or in combination with other potential markers to verify CSCs [30-32], and it is highly expressed in several tumors such as those of the ovary, breast, and pancreas [33-35]. CD44+ cells have been identified in primary tissues, metastatic tissues, and malignant ascites of ovarian cancer [36]; one hundred CD44+/CD117+ cells are sufficient to propagate the original tumor, but CD44-/CD117- cells are not [30]. CD44 increases invasion and migration activity in non-malignant ovarian cancer cells via exosome transfer [37]. CD44 elevates chemoresistance and invasion activity through a signal transducer and activator of transcription 3 (STAT3)-dependent mechanism, and it influences angiogenesis and 
immunosuppression in the tumor microenvironment via the secretion of various angiogenic factors and cytokines, including vascular endothelial growth factor and interleukin 6 [38]. Despite the function of CD44 as a stem cell biomarker, contradictory findings suggest that CD44 fails to function as a prognostic factor in ovarian cancer $[39,40]$. Nevertheless, CD44 can be utilized as an outstanding prognostic marker in combination with other putative biomarkers $[41,42]$.

\section{2. $C D 117$}

CD117, generally known as c-kit, is a receptor tyrosine kinase that is involved in various signaling pathways responsible for the survival, proliferation, migration, tumor progression, and stemness $[19,43]$ of CSCs, and it is a common marker of hematopoietic stem cells, mesenchymal stem cells (MSCs), and embryonic stem cells [44]. CD117, in combination with CD44, has been used to identify CSCs [30]. CD117+ ovarian cancer cells overexpress SOX2, octamer-binding transcription factor 4 (OCT4), and NANOG, which are CSC markers involved in stemness and chemoresistance [45]. CD117 overexpression in ovarian CSCs elevates tumor-initiating capacity and chemoresistance against cisplatin/paclitaxel via the induction of the Wnt/beta-catenin-ATP-Binding Cassette Subfamily G Member 2 (ABCG2) axis [46]. In contrast, miRNA-26b is under-regulated in human CD117+CD44+ ovarian CSCs. miRNA-26b overexpression inhibits cell proliferation and promotes cell apoptosis [47]. According to a meta-analysis, CD117 expression significantly correlates with patient age, tumor differentiation grade, advanced stage, and histological type, and CD117 overexpression is associated with poor overall survival in ovarian cancer [48].

\section{3. $C D 24$}

CD24, which encodes a glycosylphosphatidylinositol-linked cell surface ligand for P-selectin, is closely associated with serous ovarian cancer [49]. CD24 has been identified as one of the most important CSC markers in several cancers, including ovarian and colorectal cancers $[50,51]$. CD24+ cells from ovarian tumor specimens regulate proliferation, self-renewal and differentiation, chemoresistance, and tumorigenicity, which are CSC characteristics [50]. CD24+ cells could recapitulate the development of the original tumor in a mouse model of ovarian cancer with the conditional deletion of Apc, Pten, and cellular tumor antigen p53 (Trp53; Mus musculus), which was confirmed through JAK2STAT3 signaling [52]. CD24 regulates epithelial-to-mesenchymal transition (EMT) by modulating the PI3K/AKT/MAPK signaling pathway [53]. The overexpression of CD24 has been reported in ovarian cancer patients, and it is a metastatic prognosis marker for poor survival $[53,54]$. Triple-positive (CD24+/CD44+/EpCAM+) cells isolated from ovarian cancer patients exhibit clonogenic potential and chemoresistance to cisplatin and doxorubicin [55]. However, the CD44+/CD24- phenotype in ovarian cancer cells determines the CSC properties of newly propagated and invasive tumors, and ovarian cancer patients with this phenotype exhibit enhanced recurrence and shorter progressionfree survival [56]. Therefore, CD24 should be used in combination with other stem cell markers, such as CD44 and epithelial cell adhesion molecule (EpCAM), for the isolation of ovarian CSCs.

\section{4. $C D 133$}

There is evidence that CD133, a glycosylated transmembrane protein, helps maintain cancer stemness and is associated with tumor metastasis [57]. CD133 has been reported as a prognostic marker and regulator of cancer metastasis in several cancers, such as ovarian cancer, glioblastoma, and prostate cancer [58-60]. Primary cancer tissues comprise $0.1 \%$ to $3 \%$ CD133+ cells; however, the proportion of CD133+ cells increases upon chemotherapy with cisplatin or paclitaxel [61]. The expression level of CD133 is elevated in sphere-forming and drug-resistant populations of ovarian cancer cells, which exhibit chemoresistance and tumorigenesis in vivo and increased levels of stemness markers such as OCT4, SOX2, and 
NANOG [62]. CD133+ cells promote non-stem cancer cell metastasis by inducing EMT via the CCL5-NF- $\mathrm{kB}$ axis [63]. Moreover, CD133 expression significantly correlates with a low survival rate in ovarian cancer [64]. Based on the aforementioned results, CD133 is a promising prognosis marker and therapeutic target for ovarian CSCs.

\subsection{CD166/ALCAM}

CD166, also known as activated leukocyte cell adhesion molecule (ALCAM), is a transmembrane glycoprotein of the immunoglobulin superfamily [65] and is expressed mainly at the cell membrane [66]. CD166 is overexpressed in various cancers, including thyroid, head and neck, lung, and liver cancers [67]. A high level of CD166 is associated with a poor prognosis in malignant melanoma, the metastasis of prostate cancer, the invasion activity of cholangiocarcinoma, and the anti-apoptotic function of breast cancer [67-70]. Cells expressing high levels of CD44/CD166 exhibit enhanced CSC-like properties and tumorigenicity. CD166 is overexpressed in tissues from recurrent tumors and is associated with poor prognosis in head and neck squamous cell carcinoma [71]. In addition, CD166 regulates the expression of CSC markers and mediates the EGFR/ERK1/2 pathway in nasopharyngeal carcinoma [72]. CD166 has been reported to play a pro-carcinogenic role in liver cancer cells by promoting the expression and activation of RAC-alpha serine/threonine-protein kinase (AKT) and yes-associated protein (YAP), which is a coactivator of Hippo signaling [73,74]. Our previous study showed that CD166 exhibits CSC-like properties in primary epithelial ovarian cancer cells. CD166 induced the expression of CSC markers such as OCT4, SOX2, and aldehyde dehydrogenase 1 A1 (ALDH1A1), and ABC transporters in both A2780derived sphere-forming cells and primary ovarian CSCs, thus promoting CSC-like properties and chemoresistance [75]. A recent report indicated that CD133+/CD166+ cells are strongly stem-like cancer cells in human gastric adenocarcinoma, and that CD133+/CD166cells exhibit self-renewal properties, colony formation capacity, and substantial migration activity [76]. These results suggest that CD166 may be a potential therapeutic target for CSCs, including ovarian CSCs.

\section{Intracellular Markers of Ovarian CSCs}

\subsection{Aldehyde dehydrogenase 1}

Aldehyde dehydrogenase (ALDH) is an enzyme that catalyzes aldehydes, which detoxify endogenous and exogenous reactive aldehydes [77]. ALDH comprises three classes: class 1 (cytosolic), class 2 (mitochondrial), and class 3 [78]. ALDH1 consists of three isozymes (ALDH1A1, ALDH1A2, and ALDH1A3); ALDH1A1 predominantly serves as a CSC marker. ALDH1 expression in ovarian cancer cells has been demonstrated in several studies $[79,80]$. Our previous study and others suggest that spheroid cells derived from ovarian cancer cell lines and primary ovarian cancer tissues are enriched with CSC-like cells exhibiting high ALDH activity, elevated stem-cell marker expression, self-renewal, high proliferation, and differentiation potential [81-83]. The ALDH1A1 subpopulation is associated with an invasive phenotype, clonogenicity, drug resistance, and worse progression-free survival in ovarian cancer patients [84,85]. Accumulating evidence suggests that ALDH1A1 regulates the maintenance of ovarian CSCs, ALDH+ ovarian cancer cells exhibit stem cell-like properties, and knock-down of ALDH1A1 in ovarian cancer cells diminishes clonogenic ability [85].

\subsection{Autotaxin}

Autotaxin (ATX), which belongs to the ectonucleotide pyrophosphatase/phosphodiester ase family, is a tumor cell motility-stimulating factor that stimulates cell motility and cell proliferation of cancer cell lines [86]. ATX exhibits lysophospholipase D activity, and it affects tumor motility and growth by producing lysophosphatidic acid (LPA) [86,87]. Several studies have shown that ATX is expressed in several tissues such as the ovary, small intestine, placenta, platelets, and adipose tissue, and body fluids such as cerebrospinal fluid [88,89]. A high expression of ATX has been detected in breast cancer, glioblastoma multiforme, prostate 
cancer, hepatocellular carcinoma, and melanoma [90-94]. ATX overexpression in these cancers promotes tumor motility and invasiveness, enhances metastatic potential, and correlates with poor outcomes in cancer patients [95]. It has been reported that ATX is responsible for maintaining ovarian CSCs via the LPA-LPAR axis. ATX-induced LPA production in A2780 sphere-forming cells enhances migration, sphere formation, and the expression of CSC markers, such as OCT4, SOX2, Kruppel-like factor 4 (KLF4), and ALDH1. Conversely, silencing ATX expression in A2780-derived spheroid cells reduces the level of stemnessrelated transcription factors such as OCT4, SOX2, and KLF4 [83]. Therefore, the ATX-LPA signaling axis may be a prominent target for the development of combination therapies for ovarian CSCs.

\subsection{Pluripotency-Associated Factors}

The pluripotent properties of CSCs, such as long-term self-renewal, multi-differentiation potential, and asymmetric division [12,96], have been attributed to common stem-related transcription factors [97]. They are derived from the embryonic transcription factors OCT4, SOX2, and NANOG, whose genes are considered stem cell signature genes [97]. These gene signatures with c-MYC (myc proto-oncogene protein) are frequently overexpressed in poorly differentiated tumors and then well differentiated in breast cancer, glioblastoma, and bladder carcinomas. The expression signatures of OCT4, SOX2, and NANOG are associated with poor clinical outcomes in breast cancer [98]. Green fluorescent protein (GFP)-labeled ovarian CSCs utilize the NANOG promoter system to overexpress OCT4, SOX2, and NANOG compared with the GFP-negative ovarian cancer cells, and the GFPpositive cells also exhibit greater cisplatin resistance and tumor initiation properties. In addition, low-dose cisplatin treatment induces stemness in ovarian cancer cells [99]. OCT4, SOX2, and NANOG are significantly overexpressed in high-grade serous ovarian cancer cell lines cultured under 3D culture conditions, and CD117+ or ALDH+/CD133+ cells exhibit elevated expression of stemness genes [45]. SOX2, but not OCT4 or NANOG, has been implicated in early tumor initiation and plays a more substantial role in tumor relapse in ovarian cancer patients. SOX2 expression is upregulated in several types of CSCs, including those of breast, gastric, lung, and ovarian cancers [100]. SOX2 with ALDH and $\mathrm{ABC}$ transporters is overexpressed under hypoxic conditions via neurogenic locus notch homolog protein 1 (NOTCH1) in ovarian CSC spheroid culture. A knockdown of SOX2 expression inhibits ovarian CSC survival and disturbs spheroid formation [101]. However, the precise regulatory mechanism of these pluripotent factors in ovarian CSCs is not understood.

\subsection{Hypoxia-inducible Factor 1-alpha (HIF-1 $\alpha)$}

Hypoxia refers to a state of insufficient oxygen supply caused by various factors, including physiological and physical states, epigenetic environments, and gene alterations [102,103]. Hypoxia is an essential hallmark of cancer cells and their microenvironment, and it confers an advantage to cancer cells during their growth, survival, and metastasis [103]. Therefore, it is important to control the hypoxic microenvironment to inhibit the malignant properties of cancer. HIF-1 $\alpha$, one of the master regulators of hypoxia adaptation, is associated with angiogenesis, glucose metabolism, cell proliferation, and drug resistance [104]. HIF-1 $\alpha$ can induce pluripotent stem cell inducers, such as OCT4, NANOG, SOX2, KLF4, c-MYC, and microRNA-302, in 11 cancer cell lines (derived from prostate, brain, kidney, cervix, lung, colon, liver, and breast cancers) [105]. Hypoxia plays an essential role in maintaining CSC characteristics, such as colony and sphere formation, and the expression of CD133 and CD44 in ovarian CSCs [106]. CD166+ lung adenocarcinoma A549 cells showed robust drug resistance and stemness owing to HIF- $1 \alpha$-induced ABCG2 under chemically induced hypoxia conditions [107]. Our previous study showed that hypoxia-induced NOTCH and HIF-1 $\alpha$ elevated SOX2 expression to promote sphere formation and drug resistance by increasing ALDH1, ATP-Binding Cassette Subfamily B Member 1 (ABCB1), and ABCG2 expression in ovarian cancer cells. In contrast, silencing 
of SOX2 in A2780-derived ovarian CSCs significantly reduced stem cell marker expression and decreased resistance to chemotherapy drugs such as doxorubicin or paclitaxel, as in ovarian cancer patient-derived sphere cells [101]. These reports suggest that controlling hypoxia signaling may be novel options to eliminate CSCs in ovarian cancer. The summary of ovarian stem cell markers and their features as mentioned above was compiled on Table 1 with the references.

Table 1. The ovarian cancer stem cell markers and their features.

\begin{tabular}{|c|c|c|}
\hline Protein Names & Features & References \\
\hline \multicolumn{3}{|c|}{ Cell surface markers of ovarian CSCs } \\
\hline CD44 & $\begin{array}{l}\text { CD44 is the most common CSC marker in the ovary, breast, and pancreas. } \\
\text { CD44+ cells have been found in primary, metastatic, and malignant ascites } \\
\text { of ovarian carcinoma. }\end{array}$ & {$[29,33-36]$} \\
\hline CD117 & $\begin{array}{l}\text { CD117 has been known as c-kit. CD117 is a receptor tyrosine kinase related } \\
\text { to survival, proliferation, migration, tumor progression, and stemness. } \\
\text { CD117 is expressed in hematopoietic, mesenchymal, embryonic stem cells. } \\
\text { CD117 is involved in stemness and chemoresistance in ovarian cancer. }\end{array}$ & {$[19,43-45]$} \\
\hline $\mathrm{CD} 24$ & $\begin{array}{l}\text { CD24 has been verified as a critical CSC marker in several cancers } \\
\text { involving ovarian and colorectal cancers. CD24 is known as the regulation } \\
\text { of proliferation, self-renewal, and chemoresistance in ovarian cancer. CD24 } \\
\text { positive expressed ovarian cancer patients is poor survival. }\end{array}$ & {$[50,51,54-57]$} \\
\hline CD133 & $\begin{array}{l}\text { CD133 is a glycosylated transmembrane protein and associated with } \\
\text { maintaining cancer stemness and tumor metastasis. CD133 has been } \\
\text { identified as a prognostic marker in several cancers such as ovarian, } \\
\text { glioblastoma, and prostate cancer. CD133 also is correlated with } \\
\text { chemoresistance and poor prognosis in ovarian cancer. }\end{array}$ & {$[58-62,65]$} \\
\hline CD166/ALCAM & $\begin{array}{l}\text { CD166 is a transmembrane glycoprotein of the immunoglobulin } \\
\text { superfamily. CD166 is overexpressed and is associated with a poor } \\
\text { prognosis in various cancers. CD166 induced intracellular cancer stem } \\
\text { markers such as OCT4, SOX2, and ALDH1A1. CD166 also is associated } \\
\text { with maintaining CSC properties and chemoresistance. }\end{array}$ & {$[66-71,76]$} \\
\hline
\end{tabular}

Intracellular markers of ovarian CSCs

ALDH1 is an enzyme to detoxify reactive aldehydes. ALDH composes three classes. ALDH1 consists of three isozymes; ALDH1A1 is

ALDH1 predominantly a CSC marker. ALDH elevated stem-cell marker expression, self-renewal, proliferation, and differentiation potential. ALDH is also associated with invasion, drug resistance, and worse progression-free survival in ovarian cancer.

Autotaxin possesses lysophospholipase D activity and produces lysophosphatidic acid (LPA). Autotaxin is expressed in several tissues,

Autotaxin including body fluid, and it is highly expressed in the breast, glioblastoma, prostate, hepatocellular carcinoma, and melanoma. Autotaxin enhances migration, sphere formation, and cancer stemness markers.

OCT4, SOX2, and NANOG are the most common intracellular cancer stem

Pluripotencyassociated factors markers in normal and cancer stem cells. Among these factors, SOX2 plays a more substantial role in early tumor initiation and tumor relapse in ovarian cancer, including breast, gastric, and lung. The knock-down SOX2 inhibits ovarian CSC survival and spheroid formation.
$[12,97,98,101,102]$

Hifla is one of the hypoxia-inducible factors and master regulators of hypoxia. Hif1a is correlated with growth, survival, and metastasis during hypoxia conditions. Hif1a can elevate the expression of pluripotent stem markers and plays an essential role in maintaining CSC properties. 


\section{Therapeutic Strategies Using CSC Markers}

\subsection{Standard and Targeted Therapies for Ovarian Cancer}

Ovarian cancer patients show a high response rate to front-line chemotherapy based on platinum-based drugs with surgical debulking [6], but they eventually relapse within several months $[9,10]$. Platinum resistance is defined as the development of recurrence within six months following first-line chemotherapy [2]. Platinum-resistant patients have been administered combined chemotherapy with or without doxorubicin, paclitaxel, gemcitabine, or targeted therapies such as the administration of bevacizumab or poly-ADP ribose polymerase (PARP) inhibitors [108]. In 2018, a phase 3 clinical trial showed that olaparib, a potent PARP inhibitor, dramatically improved the disease-free survival of ovarian cancer patients carrying the breast cancer type susceptibility protein $1 / 2$ (BRCA1/2) mutation by $70 \%$ (3 years) compared with the placebo $[109,110]$. However, BRCA wild-type ovarian cancer patients showed a lower response rate to PARP inhibitors [109,111]. PARP inhibitor resistance and recurrence have been reported in ovarian [112] and breast cancers [113]. Combined therapy with other targeted therapeutic drugs, including PI3K, cyclin-dependent kinase $1(\mathrm{Cdk} 1)$, and hepatocyte growth factor receptor (c-MET) inhibitors, was attempted to overcome PARP inhibitor resistance [1]. PARP inhibitor treatment induced cell apoptosis in non-ovarian CSCs but enriched CD133+ and CD117+ ovarian CSCs by increasing DNA repair ability in a BRCA mutation-independent manner [114], suggesting that ovarian CSCs may exhibit intrinsic or acquired resistance against PARP inhibitor treatment, leading to relapse. Therefore, it is essential to eliminate ovarian CSCs from ovarian cancer patients.

CSC surface markers are more accessible to therapeutic antibodies and small molecules than other CSC markers; thus, it is a feasible target that can be utilized to treat various cancers [115]. Moreover, considering the function of CSC markers in maintaining CSC properties, it is straightforward to isolate specific CSCs and use the diagnostic markers for predicting patient survival. Although there are several debates on the isolation and targeting of CSC surface markers, many researchers believe that eliminating specific CSCs can eradicate whole cancer tissues $[14,116,117]$. Numerous studies have shown that targeting CSC surface markers using specific antibodies and small molecules effectively abrogates cancer growth [118]. Targeting not only the surface markers but also intracellular CSC markers, such as ALDH1, Autotaxin, Oct4, Sox2, Nanog, and Hif1a, has been shown many feasibilities to alleviate ovarian CSCs growth and maintenance via small molecule inhibitors or gene knock-down $[45,84,86,102,106]$. However, many CSC markers have various obstacles to apply on the clinical side due to the limitation of selection and targeting for CSCs.

Targeting CSCs of ovarian cancer has two challenges in clinical application. First, CSC markers cannot explicitly distinguish CSCs from normal stem cells, such as embryonic, hematopoietic, neural, and mesenchymal stem cells. Approximately $73 \%$ of currently known CSC surface markers are present on embryonic or adult stem cells [115]. CSC properties, including self-renewal and multi-differentiation potential, are very similar to those of normal stem cells $[28,115]$. Therefore, these CSC markers are known to originate from cell surface markers of embryonic and adult stem cells $[14,116,117,119,120]$. In addition, CSCs can arise from the accumulation of epigenetic and genetic alterations in normal stem cells [28]. Some CSC markers have also been detected in normal cells or tissues. Although CD133 is a marker that can be used to distinguish CSCs from various cancer tissues, such as breast, brain, lung, pancreas, liver, prostate, ovary, colon, and head and neck cancers [58], it has also been detected on the surface of differentiated epithelial cells [115]. CD24 has been identified as a CSC marker in a wide range of cancers and has been detected in B cell precursors, neutrophils, neuronal cells, and various epithelial cells [121]. CD117 expression is $24 \%$ positive in human embryonic stem cells [122,123]. CD166 is a surface marker in colorectal CSCs and non-small cell lung cancer [124,125]; however, it is also found in many epithelial cells, and it is a marker of human mesenchymal stem cells and intestinal stem cells $[126,127]$. CD44 is a marker that has been isolated from various solid tumors [128,129], and it is found in human hematopoietic stem cells, MSCs, 
and adipose-derived stem cells [130-132]. Moreover, most intracellular CSC markers, such as Wnt, Notch, Sonic hedgehog, fibroblast growth factor, NANOG, OCT4, SOX2, and MYC, have been detected in normal stem cells. These markers play an essential role in maintaining stem cell properties [98,133-135]. CSC markers, such as CD117, CD133, CD24, CD44, OCT4, stage-specific embryonic antigen 4 (SSEA4), leucine-rich repeat-containing G-protein coupled receptor 5 (LGR5), and ALDH1/2 with Ki-67 expression, have been identified in ovarian epithelial cells and cortex regions, although the expression of the markers differed slightly between them [136]. Therefore, the utilization of stem cell markers expressed in normal stem cells or tissues as therapeutic targets against CSCs can lead to the eradication of normal stem cells and disturb normal tissue regeneration or reorganization.

The other challenge is that there is no universal consensus CSC marker to isolate and target all types of CSCs simultaneously. There are multiple types of ovarian CSCs due to intratumoral heterogeneity [137]. The expression of CSC markers, which are already known as potent CSC markers, might be affected according to the differentiation status of CSC and be influenced by splicing variant expression $[136,138,139]$. For instance, the CD44+/CD24- ovarian cancer cells have CSC-like properties such as tumor-initiating ability and invasion [56]. The CD133+/CD166- ovarian cancer cells possess CSC traits including self-renewal, colony formation, and migration activity [76]. Furthermore, CD133 is expressed on both CSC and differentiated tumor cells but is probably differentially folded as a result of differential glycosylation to mask specific epitopes [140]. CD44specific variants (v8-v10 isoform) have been reported as a CSC-specific marker in gastric cancer $[139,141]$. The results suggest that targeting specific surface markers is not enough to eradicate ovarian CSCs due to the heterogeneity of CSCs. Therefore, it is necessary to isolate and verify more CSC-specific functional markers to distinguish CSCs from normal adult stem cells.

\subsection{Future Directions of CSC-Targeting Therapy}

Many researchers have chosen to eradicate CSCs in cancer tissues because these cells are the main factor in building the cancer microenvironment, and they have strongly focused on studying more specific CSC surface markers to distinguish them from those of other cancer or stem cells. However, the application prospect of CSC surface markers is debatable. It is challenging to target a particular CSC surface marker to completely eradicate ovarian CSCs. Therefore, the aforementioned alternative therapy entailed the targeting of at least two CSC markers. For example, CD133 and CD44 aptamer-conjugated dual-targeted nanomicelles loaded with gefitinib, an epidermal growth factor receptor (EGFR) inhibitor, more effectively eradicated CD133/CD44 double-positive lung cancerinitiating cells compared with the single-targeted or non-targeted nanomicelles [142]. Anti-CD24/anti-mesothelin dual-chimeric antigen receptor-natural killer cell (CAR-NK) therapy significantly increased the drug response rate compared with therapy using singletarget NK cells. This dual-target strategy was applicable because mesothelin was detected in $42 \%$ of ovarian cancer patients [143]. Although the single-target CSC surface marker strategy is sufficient to eliminate ovarian CSCs both in vitro and in vivo, dual marker targeting is more effective in increasing the drug response rate and eradicating ovarian CSCs, including CSCs expressing a single marker. Therefore, dual marker targeting to eliminate CSCs may be a more promising therapeutic method. However, there are many challenges in establishing a therapeutic method and undertaking clinical trials.

Ovarian CSCs are not only involved in the formation of ovarian cancer but constantly interact with the microenvironment around them, including other cells and extracellular components. Notably, cancer-associated fibroblasts, stromal cells, and MSCs in tumor tissues play pivotal roles in cancer malignancy, including cancer growth, invasion, and metastasis. These interactions appear to have positive cross-reactivity through auto- and paracrine signaling. Hence, breaking off the communication between CSCs and the microenvironment, including cancer-associated cells, is essential to eradicate CSCs. The biomarkers that are differentially expressed in normal tissue and cancer-associated cells need to be 
discovered, and their connection with these interactions should be elucidated. When both cancer cells and adult MSCs were co-inoculated into an immunodeficient mouse model, adult MSCs differentiated into cancer-associated fibroblasts owing to auto- and paracrine factors from cancer cells, and these cells increased the growth and invasion of the cancer cells $[144,145]$. The ATX-LPA-LPAR1 axis plays an important role in such interactions with cancer cells and adult stem cells in cancer tissues. The inhibition of ATX or LPAR1 using siRNA or small molecules disturbs the differentiation of MSC-derived fibroblasts, and it reduces the metastasis, migration, and cell proliferation of cancer cells [146-149]. Cancer-associated MSCs induce chemoresistance in ovarian CSCs via platelet-derived growth factor (PDGF) signaling. Combined therapy with sonidegib, a PDGF receptor (PDGFR) inhibitor, and carboplatin broke up the connection between MSCs and ovarian CSCs. The inhibition of PDGFR signaling via sonidegib increased the sensitivity of ovarian CSCs to carboplatin [150]. Therefore, it is likely that the inhibition of both ovarian CSCs and cancer-associated MSCs in the microenvironment is a feasible therapeutic strategy for ovarian cancer (Figure 2).

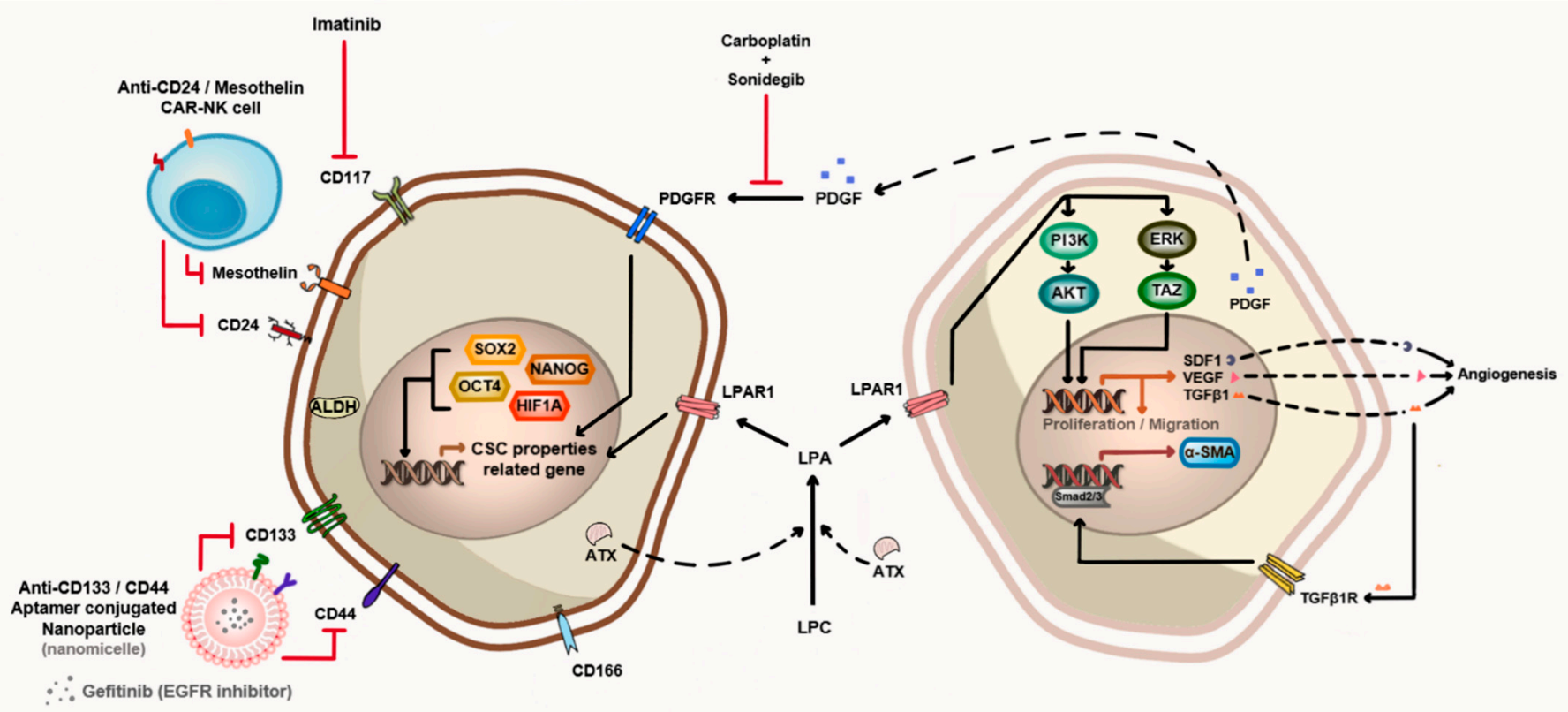

Cancer Stem Cell

Cancer - Associated Cell

Figure 2. Microenvironment between cancer stem cells and cancer-associated cells in tumor tissue. Cancer stem cells have several surface markers that can be isolated and targeted, such as CD44, CD117, CD24, CD133, and CD166. Cancer stem cells overexpress pluripotent proteins, including ALDH1, ATX, HIF-1 $\alpha$, OCT4, SOX2, and NANOG, which regulate cancer stem cell properties by mediating the expression of surface markers, cytokines, and growth factors. ATX produces LPA, which induces cancer-associated cells to differentiate into myofibroblasts via the TGF-b1-Samd2/3 axis. LPAR1 activation by LPA triggers cell proliferation and migration (homing) toward cancer tissues. Cancer-associated cells secrete PDGF to activate PDGFR in cancer stem cells, thereby maintaining cancer stem cell properties.

\section{Conclusions and Perspectives}

CSCs have been implicated in chemoresistance, as well as the tumorigenesis, migration, and invasion of ovarian cancer cells. In patients with ovarian cancer, normal stem cells can be also damaged if CSC-targeted therapy is performed. Therefore, it is necessary to identify more specific markers to selectively eliminate ovarian CSCs. The CSC-targeting antibody can be applied for targeted therapy of cancer via drug conjugation and combination therapy with conventional anti-cancer drugs. Moreover, the CSC-targeting antibody may be useful for development of new technologies targeting the CSCs, including dual- 
specific antibodies and CAR-T cells. In addition to the direct targeting of CSCs, it will be needed to interfere intercellular communication within the tumor microenvironment to eradicate ovarian CSCs. Moreover, drugs targeting the autotaxin-LPA-LPAR signaling cascade will be highly beneficial for therapy of cancer through abrogating self-renewal and drug-resistant properties of CSCs. Therefore, for effective therapy of ovarian cancer patients, it will be needed to develop CSC-specific antibodies and CSC-targeting therapeutics including chemical drugs, antibody drug conjugates, and CAR-T.

Author Contributions: Conceptualization, W.Y. and J.H.K.; investigation, W.Y. and D.K.K.; writingoriginal draft preparation, W.Y.; writing—review and editing, W.Y., D.K.K., K.U.C., D.S.S., and J.H.K.; supervision, J.H.K.; project administration, J.H.K.; and D.K. had contributed illustrations. All authors have read and agreed to the published version of the manuscript.

Funding: This study was supported by the MRC (NRF-2015R1A5A2009656) and Basic Science Research programs (NRF-2021R1A2C1012164, NRF-2020R1I1A3073064, and NRF-2020R1A2C2011880) of the National Research Foundation of Korea (NRF), funded by the Ministry of Education.

Conflicts of Interest: The authors declare no conflict of interest.

\section{References}

1. Bray, F.; Ferlay, J.; Soerjomataram, I.; Siegel, R.L.; Torre, L.A.; Jemal, A. Global cancer statistics 2018: GLOBOCAN estimates of incidence and mortality worldwide for 36 cancers in 185 countries. CA Cancer J. Clin. 2018, 68, 394-424. [CrossRef]

2. Cortez, A.J.; Tudrej, P.; Kujawa, K.A.; Lisowska, K.M. Advances in ovarian cancer therapy. Cancer Chemother. Pharmacol. 2018, 81, 17-38. [CrossRef]

3. Lengyel, E. Ovarian cancer development and metastasis. Am. J. Pathol. 2010, 177, 1053-1064. [CrossRef]

4. Vaughan, S.; Coward, J.I.; Bast, R.C., Jr.; Berchuck, A.; Berek, J.S.; Brenton, J.D.; Coukos, G.; Crum, C.C.; Drapkin, R.; Etemadmoghadam, D.; et al. Rethinking ovarian cancer: Recommendations for improving outcomes. Nat. Rev. Cancer 2011, 11, 719-725. [CrossRef]

5. Lalwani, N.; Prasad, S.R.; Vikram, R.; Shanbhogue, A.K.; Huettner, P.C.; Fasih, N. Histologic, molecular, and cytogenetic features of ovarian cancers: Implications for diagnosis and treatment. Radiographics 2011, 31, 625-646. [CrossRef]

6. Marchetti, C.; Pisano, C.; Facchini, G.; Bruni, G.S.; Magazzino, F.P.; Losito, S.; Pignata, S. First-line treatment of advanced ovarian cancer: Current research and perspectives. Expert Rev. Anticancer Ther. 2010, 10, 47-60. [CrossRef]

7. Kartal-Yandim, M.; Adan-Gokbulut, A.; Baran, Y. Molecular mechanisms of drug resistance and its reversal in cancer. Crit. Rev. Biotechnol. 2016, 36, 716-726. [CrossRef]

8. Yousefi, B.; Zarghami, N.; Samadi, N.; Majidinia, M. Peroxisome Proliferator-Activated Receptors and their Ligands in Cancer Drug- Resistance: Opportunity or Challenge. Anti-Cancer Agents Med. Chem. 2016, 16, 1541-1548. [CrossRef]

9. Colombo, N.; Lorusso, D.; Scollo, P. Impact of Recurrence of Ovarian Cancer on Quality of Life and Outlook for the Future. Int. J. Gynecol. Cancer Off. J. Int. Gynecol. Cancer Soc. 2017, 27, 1134-1140. [CrossRef] [PubMed]

10. Colombo, N.; Van Gorp, T.; Parma, G.; Amant, F.; Gatta, G.; Sessa, C.; Vergote, I. Ovarian cancer. Crit. Rev. Oncol./Hematol. 2006, 60, 159-179. [CrossRef]

11. Amoroso, M.R.; Matassa, D.S.; Agliarulo, I.; Avolio, R.; Maddalena, F.; Condelli, V.; Landriscina, M.; Esposito, F. Stress-Adaptive Response in Ovarian Cancer Drug Resistance: Role of TRAP1 in Oxidative Metabolism-Driven Inflammation. Adv. Protein Chem. Struct. Biol. 2017, 108, 163-198. [CrossRef]

12. Yu, Z.; Pestell, T.G.; Lisanti, M.P.; Pestell, R.G. Cancer stem cells. Int. J. Biochem. Cell Biol. 2012, 44, 2144-2151. [CrossRef]

13. Colak, S.; Medema, J.P. Cancer stem cells-Important players in tumor therapy resistance. FEBS J. 2014, 281, 4779-4791. [CrossRef] [PubMed]

14. Visvader, J.E.; Lindeman, G.J. Cancer stem cells in solid tumours: Accumulating evidence and unresolved questions. Nat. Rev. Cancer 2008, 8, 755-768. [CrossRef] [PubMed]

15. Maugeri-Saccà, M.; Vigneri, P.; De Maria, R. Cancer stem cells and chemosensitivity. Clin. Cancer Res. Off. J. Am. Assoc. Cancer Res. 2011, 17, 4942-4947. [CrossRef] [PubMed]

16. Carnero, A.; Garcia-Mayea, Y.; Mir, C.; Lorente, J.; Rubio, I.T.; ME, L.L. The cancer stem-cell signaling network and resistance to therapy. Cancer Treat. Rev. 2016, 49, 25-36. [CrossRef]

17. Singh, A.; Settleman, J. EMT, cancer stem cells and drug resistance: An emerging axis of evil in the war on cancer. Oncogene 2010, 29, 4741-4751. [CrossRef]

18. Rahman, M.; Deleyrolle, L.; Vedam-Mai, V.; Azari, H.; Abd-El-Barr, M.; Reynolds, B.A. The cancer stem cell hypothesis: Failures and pitfalls. Neurosurgery 2011, 68, 531-545. [CrossRef]

19. Mihanfar, A.; Aghazadeh Attari, J.; Mohebbi, I.; Majidinia, M.; Kaviani, M.; Yousefi, M.; Yousefi, B. Ovarian cancer stem cell: A potential therapeutic target for overcoming multidrug resistance. J. Cell. Physiol. 2019, 234, 3238-3253. [CrossRef] 
20. Keyvani, V.; Farshchian, M.; Esmaeili, S.A.; Yari, H.; Moghbeli, M.; Nezhad, S.K.; Abbaszadegan, M.R. Ovarian cancer stem cells and targeted therapy. J. Ovarian Res. 2019, 12, 120. [CrossRef]

21. Bapat, S.A.; Mali, A.M.; Koppikar, C.B.; Kurrey, N.K. Stem and progenitor-like cells contribute to the aggressive behavior of human epithelial ovarian cancer. Cancer Res. 2005, 65, 3025-3029. [CrossRef]

22. Zou, K.; Yuan, Z.; Yang, Z.; Luo, H.; Sun, K.; Zhou, L.; Xiang, J.; Shi, L.; Yu, Q.; Zhang, Y.; et al. Production of offspring from a germline stem cell line derived from neonatal ovaries. Nat. Cell Biol. 2009, 11, 631-636. [CrossRef]

23. Paik, D.Y.; Janzen, D.M.; Schafenacker, A.M.; Velasco, V.S.; Shung, M.S.; Cheng, D.; Huang, J.; Witte, O.N.; Memarzadeh, S. Stem-like epithelial cells are concentrated in the distal end of the fallopian tube: A site for injury and serous cancer initiation. Stem Cells 2012, 30, 2487-2497. [CrossRef] [PubMed]

24. Flesken-Nikitin, A.; Hwang, C.I.; Cheng, C.Y.; Michurina, T.V.; Enikolopov, G.; Nikitin, A.Y. Ovarian surface epithelium at the junction area contains a cancer-prone stem cell niche. Nature 2013, 495, 241-245. [CrossRef] [PubMed]

25. Szotek, P.P.; Pieretti-Vanmarcke, R.; Masiakos, P.T.; Dinulescu, D.M.; Connolly, D.; Foster, R.; Dombkowski, D.; Preffer, F.; Maclaughlin, D.T.; Donahoe, P.K. Ovarian cancer side population defines cells with stem cell-like characteristics and Mullerian Inhibiting Substance responsiveness. Proc. Natl. Acad. Sci. USA 2006, 103, 11154-11159. [CrossRef] [PubMed]

26. Dubeau, L.; Drapkin, R. Coming into focus: The nonovarian origins of ovarian cancer. Ann. Oncol. Off. J. Eur. Soc. Med. Oncol. 2013, 24, viii28-viii35. [CrossRef]

27. Flesken-Nikitin, A.; Choi, K.C.; Eng, J.P.; Shmidt, E.N.; Nikitin, A.Y. Induction of carcinogenesis by concurrent inactivation of p53 and $\mathrm{Rb} 1$ in the mouse ovarian surface epithelium. Cancer Res. 2003, 63, 3459-3463. [PubMed]

28. Lee, H.Y.; Hong, I.S. Double-edged sword of mesenchymal stem cells: Cancer-promoting versus therapeutic potential. Cancer Sci. 2017, 108, 1939-1946. [CrossRef] [PubMed]

29. Sherman, L.; Sleeman, J.; Herrlich, P.; Ponta, H. Hyaluronate receptors: Key players in growth, differentiation, migration and tumor progression. Curr. Opin. Cell Biol. 1994, 6, 726-733. [CrossRef]

30. Zhang, S.; Balch, C.; Chan, M.W.; Lai, H.C.; Matei, D.; Schilder, J.M.; Yan, P.S.; Huang, T.H.; Nephew, K.P. Identification and characterization of ovarian cancer-initiating cells from primary human tumors. Cancer Res. 2008, 68, 4311-4320. [CrossRef] [PubMed]

31. Yan, Y.; Zuo, X.; Wei, D. Concise Review: Emerging Role of CD44 in Cancer Stem Cells: A Promising Biomarker and Therapeutic Target. Stem Cells Transl. Med. 2015, 4, 1033-1043. [CrossRef]

32. Sacks, J.D.; Barbolina, M.V. Expression and Function of CD44 in Epithelial Ovarian Carcinoma. Biomolecules 2015, 5, 3051-3066. [CrossRef]

33. Xu, H.; Tian, Y.; Yuan, X.; Liu, Y.; Wu, H.; Liu, Q.; Wu, G.S.; Wu, K. Enrichment of CD44 in basal-type breast cancer correlates with EMT, cancer stem cell gene profile, and prognosis. Onco Targets 2016, 9, 431-444. [CrossRef]

34. Zhao, S.; Chen, C.; Chang, K.; Karnad, A.; Jagirdar, J.; Kumar, A.P.; Freeman, J.W. CD44 Expression Level and Isoform Contributes to Pancreatic Cancer Cell Plasticity, Invasiveness, and Response to Therapy. Clin. Cancer Res. Off. J. Am. Assoc. Cancer Res. 2016, 22, 5592-5604. [CrossRef] [PubMed]

35. Lin, J.; Ding, D. The prognostic role of the cancer stem cell marker CD44 in ovarian cancer: A meta-analysis. Cancer Cell Int. 2017, 17, 8. [CrossRef] [PubMed]

36. Alvero, A.B.; Chen, R.; Fu, H.H.; Montagna, M.; Schwartz, P.E.; Rutherford, T.; Silasi, D.A.; Steffensen, K.D.; Waldstrom, M.; Visintin, I.; et al. Molecular phenotyping of human ovarian cancer stem cells unravels the mechanisms for repair and chemoresistance. Cell Cycle 2009, 8, 158-166. [CrossRef] [PubMed]

37. Shen, X.; Wang, C.; Zhu, H.; Wang, Y.; Wang, X.; Cheng, X.; Ge, W.; Lu, W. Exosome-mediated transfer of CD44 from highmetastatic ovarian cancer cells promotes migration and invasion of low-metastatic ovarian cancer cells. J. Ovarian Res. 2021, 14, 38. [CrossRef]

38. Martincuks, A.; Li, P.C.; Zhao, Q.; Zhang, C.; Li, Y.J.; Yu, H.; Rodriguez-Rodriguez, L. CD44 in Ovarian Cancer Progression and Therapy Resistance-A Critical Role for STAT3. Front. Oncol. 2020, 10, 589601. [CrossRef]

39. Zhang, J.; Chang, B.; Liu, J. CD44 standard form expression is correlated with high-grade and advanced-stage ovarian carcinoma but not prognosis. Hum. Pathol. 2013, 44, 1882-1889. [CrossRef]

40. Bartakova, A.; Michalova, K.; Presl, J.; Vlasak, P.; Kostun, J.; Bouda, J. CD44 as a cancer stem cell marker and its prognostic value in patients with ovarian carcinoma. J. Obstet. Gynaecol. 2018, 38, 110-114. [CrossRef]

41. Papadaki, C.; Manolakou, S.; Lagoudaki, E.; Pontikakis, S.; Ierodiakonou, D.; Vogiatzoglou, K.; Messaritakis, I.; Trypaki, M.; Giannikaki, L.; Sfakianaki, M.; et al. Correlation of PKM2 and CD44 Protein Expression with Poor Prognosis in Platinum-Treated Epithelial Ovarian Cancer: A Retrospective Study. Cancers 2020, 12, 1013. [CrossRef]

42. Bonneau, C.; Rouzier, R.; Geyl, C.; Cortez, A.; Castela, M.; Lis, R.; Daraï, E.; Touboul, C. Predictive markers of chemoresistance in advanced stages epithelial ovarian carcinoma. Gynecol. Oncol. 2015, 136, 112-120. [CrossRef] [PubMed]

43. Foster, B.M.; Zaidi, D.; Young, T.R.; Mobley, M.E.; Kerr, B.A. CD117/c-kit in Cancer Stem Cell-Mediated Progression and Therapeutic Resistance. Biomedicines 2018, 6, 31. [CrossRef]

44. Bast, R.C., Jr.; Hennessy, B.; Mills, G.B. The biology of ovarian cancer: New opportunities for translation. Nat. Rev. Cancer 2009, 9, 415-428. [CrossRef] 
45. Robinson, M.; Gilbert, S.F.; Waters, J.A.; Lujano-Olazaba, O.; Lara, J.; Alexander, L.J.; Green, S.E.; Burkeen, G.A.; Patrus, O.; Sarwar, Z.; et al. Characterization of SOX2, OCT4 and NANOG in Ovarian Cancer Tumor-Initiating Cells. Cancers 2021, 13, 262. [CrossRef]

46. Chau, W.K.; Ip, C.K.; Mak, A.S.; Lai, H.C.; Wong, A.S. c-Kit mediates chemoresistance and tumor-initiating capacity of ovarian cancer cells through activation of Wnt/ $\beta$-catenin-ATP-binding cassette G2 signaling. Oncogene 2013, 32, 2767-2781. [CrossRef] [PubMed]

47. Gao, Z.; Ye, X.; Bordeaux, A.; Hettich, S.; Lin, S.; Han, F.; Jia, Y. miR-26b regulates cell proliferation and apoptosis of CD117+CD44+ ovarian cancer stem cells by targeting PTEN. Eur. J. Histochem. EJH 2021, 65. [CrossRef]

48. Yang, B.; Yan, X.; Liu, L.; Jiang, C.; Hou, S. Overexpression of the cancer stem cell marker CD117 predicts poor prognosis in epithelial ovarian cancer patients: Evidence from meta-analysis. Onco Targets 2017, 10, 2951-2961. [CrossRef]

49. Soltesz, B.; Lukacs, J.; Szilagyi, E.; Marton, E.; Szilagyi Bonizs, M.; Penyige, A.; Poka, R.; Nagy, B. Expression of CD24 in plasma, exosome and ovarian tissue samples of serous ovarian cancer patients. J. Biotechnol. 2019, 298, 16-20. [CrossRef]

50. Gao, M.Q.; Choi, Y.P.; Kang, S.; Youn, J.H.; Cho, N.H. CD24+ cells from hierarchically organized ovarian cancer are enriched in cancer stem cells. Oncogene 2010, 29, 2672-2680. [CrossRef]

51. Yeung, T.M.; Gandhi, S.C.; Wilding, J.L.; Muschel, R.; Bodmer, W.F. Cancer stem cells from colorectal cancer-derived cell lines. Proc. Natl. Acad. Sci. USA 2010, 107, 3722-3727. [CrossRef]

52. Burgos-Ojeda, D.; Wu, R.; McLean, K.; Chen, Y.C.; Talpaz, M.; Yoon, E.; Cho, K.R.; Buckanovich, R.J. CD24+ Ovarian Cancer Cells Are Enriched for Cancer-Initiating Cells and Dependent on JAK2 Signaling for Growth and Metastasis. Mol. Cancer Ther. 2015, 14, 1717-1727. [CrossRef]

53. Nakamura, K.; Terai, Y.; Tanabe, A.; Ono, Y.J.; Hayashi, M.; Maeda, K.; Fujiwara, S.; Ashihara, K.; Nakamura, M.; Tanaka, Y.; et al. CD24 expression is a marker for predicting clinical outcome and regulates the epithelial-mesenchymal transition in ovarian cancer via both the Akt and ERK pathways. Oncol. Rep. 2017, 37, 3189-3200. [CrossRef] [PubMed]

54. Kristiansen, G.; Denkert, C.; Schlüns, K.; Dahl, E.; Pilarsky, C.; Hauptmann, S. CD24 is expressed in ovarian cancer and is a new independent prognostic marker of patient survival. Am. J. Pathol. 2002, 161, 1215-1221. [CrossRef]

55. Wei, X.; Dombkowski, D.; Meirelles, K.; Pieretti-Vanmarcke, R.; Szotek, P.P.; Chang, H.L.; Preffer, F.I.; Mueller, P.R.; Teixeira, J.; MacLaughlin, D.T.; et al. Mullerian inhibiting substance preferentially inhibits stem/progenitors in human ovarian cancer cell lines compared with chemotherapeutics. Proc. Natl. Acad. Sci. USA 2010, 107, 18874-18879. [CrossRef] [PubMed]

56. Meng, E.; Long, B.; Sullivan, P.; McClellan, S.; Finan, M.A.; Reed, E.; Shevde, L.; Rocconi, R.P. CD44+/CD24- ovarian cancer cells demonstrate cancer stem cell properties and correlate to survival. Clin. Exp. Metastasis 2012, 29, 939-948. [CrossRef] [PubMed]

57. Horst, D.; Kriegl, L.; Engel, J.; Kirchner, T.; Jung, A. Prognostic significance of the cancer stem cell markers CD133, CD44, and CD166 in colorectal cancer. Cancer Investig. 2009, 27, 844-850. [CrossRef]

58. Grosse-Gehling, P.; Fargeas, C.A.; Dittfeld, C.; Garbe, Y.; Alison, M.R.; Corbeil, D.; Kunz-Schughart, L.A. CD133 as a biomarker for putative cancer stem cells in solid tumours: Limitations, problems and challenges. J. Pathol. 2013, 229, 355-378. [CrossRef]

59. Schmohl, J.U.; Vallera, D.A. CD133, Selectively Targeting the Root of Cancer. Toxins 2016, 8, 165. [CrossRef]

60. Liou, G.Y. CD133 as a regulator of cancer metastasis through the cancer stem cells. Int. J. Biochem. Cell B 2019, 106, 1-7. [CrossRef]

61. Abubaker, K.; Latifi, A.; Luwor, R.; Nazaretian, S.; Zhu, H.; Quinn, M.A.; Thompson, E.W.; Findlay, J.K.; Ahmed, N. Short-term single treatment of chemotherapy results in the enrichment of ovarian cancer stem cell-like cells leading to an increased tumor burden. Mol. Cancer 2013, 12, 24. [CrossRef]

62. Liu, C.L.; Chen, Y.J.; Fan, M.H.; Liao, Y.J.; Mao, T.L. Characteristics of CD133-Sustained Chemoresistant Cancer Stem-Like Cells in Human Ovarian Carcinoma. Int. J. Mol. Sci. 2020, 21, 6467. [CrossRef] [PubMed]

63. Long, H.; Xiang, T.; Qi, W.; Huang, J.; Chen, J.; He, L.; Liang, Z.; Guo, B.; Li, Y.; Xie, R.; et al. CD133+ ovarian cancer stem-like cells promote non-stem cancer cell metastasis via CCL5 induced epithelial-mesenchymal transition. Oncotarget 2015, 6, 5846-5859. [CrossRef]

64. Zhang, J.; Guo, X.; Chang, D.Y.; Rosen, D.G.; Mercado-Uribe, I.; Liu, J. CD133 expression associated with poor prognosis in ovarian cancer. Mod. Pathol. 2012, 25, 456-464. [CrossRef] [PubMed]

65. Swart, G.W. Activated leukocyte cell adhesion molecule (CD166/ALCAM): Developmental and mechanistic aspects of cell clustering and cell migration. Eur. J. Cell Biol. 2002, 81, 313-321. [CrossRef]

66. Kahlert, C.; Weber, H.; Mogler, C.; Bergmann, F.; Schirmacher, P.; Kenngott, H.G.; Matterne, U.; Mollberg, N.; Rahbari, N.N.; Hinz, U.; et al. Increased expression of ALCAM/CD166 in pancreatic cancer is an independent prognostic marker for poor survival and early tumour relapse. Br. J. Cancer 2009, 101, 457-464. [CrossRef] [PubMed]

67. Weidle, U.H.; Eggle, D.; Klostermann, S.; Swart, G.W. ALCAM/CD166: Cancer-related issues. Cancer Genom. Proteom. 2010, 7, 231-243.

68. Adisakwattana, P.; Suwandittakul, N.; Petmitr, S.; Wongkham, S.; Sangvanich, P.; Reamtong, O. ALCAM is a Novel Cytoplasmic Membrane Protein in TNF- $\alpha$ Stimulated Invasive Cholangiocarcinoma Cells. Asian Pac. J. Cancer Prev. APJCP 2015, 16, 3849-3856. [CrossRef]

69. Hansen, A.G.; Arnold, S.A.; Jiang, M.; Palmer, T.D.; Ketova, T.; Merkel, A.; Pickup, M.; Samaras, S.; Shyr, Y.; Moses, H.L.; et al. ALCAM/CD166 is a TGF- $\beta$-responsive marker and functional regulator of prostate cancer metastasis to bone. Cancer Res. 2014, 74, 1404-1415. [CrossRef] 
70. Jezierska, A.; Matysiak, W.; Motyl, T. ALCAM/CD166 protects breast cancer cells against apoptosis and autophagy. Med. Sci. Monit. Int. Med. J. Exp. Clin. Res. 2006, 12, Br263-Br273.

71. Yan, M.; Yang, X.; Wang, L.; Clark, D.; Zuo, H.; Ye, D.; Chen, W.; Zhang, P. Plasma membrane proteomics of tumor spheres identify CD166 as a novel marker for cancer stem-like cells in head and neck squamous cell carcinoma. Mol. Cell Proteom. 2013, 12, 3271-3284. [CrossRef]

72. Chen, X.; Liang, R.; Lin, H.; Chen, K.; Chen, L.; Tian, G.; Zhu, X. CD166 promotes cancer stem cell-like phenotype via the EGFR/ERK1/2 pathway in the nasopharyngeal carcinoma cell line CNE-2R. Life Sci. 2021, 267, 118983. [CrossRef]

73. Yu, W.; Wang, J.; Ma, L.; Tang, X.; Qiao, Y.; Pan, Q.; Yu, Y.; Sun, F. CD166 plays a pro-carcinogenic role in liver cancer cells via inhibition of FOXO proteins through AKT. Oncol. Rep. 2014, 32, 677-683. [CrossRef] [PubMed]

74. Ma, L.; Wang, J.; Lin, J.; Pan, Q.; Yu, Y.; Sun, F. Cluster of differentiation 166 (CD166) regulated by phosphatidylinositide 3-Kinase (PI3K)/AKT signaling to exert its anti-apoptotic role via yes-associated protein (YAP) in liver cancer. J. Biol. Chem. 2014, 289, 6921-6933. [CrossRef]

75. Kim, D.K.; Ham, M.H.; Lee, S.Y.; Shin, M.J.; Kim, Y.E.; Song, P.; Suh, D.S.; Kim, J.H. CD166 Promotes the Cancer Stem-like Properties of Primary Epithelial Ovarian Cancer Cells. BMB Rep. 2020, 53, 622-627. [CrossRef] [PubMed]

76. Ni, T.; Wang, H.; Zhan, D.; Tao, L.; Lv, M.; Wang, W.; Chu, Z.; Zhou, Z.; Sunagawa, M.; Liu, Y. CD133+/CD166+ human gastric adenocarcinoma cells present the properties of neoplastic stem cells and emerge more malignant features. Life Sci. 2021, 269, 119021. [CrossRef] [PubMed]

77. Ikawa, M.; Impraim, C.C.; Wang, G.; Yoshida, A. Isolation and characterization of aldehyde dehydrogenase isozymes from usual and atypical human livers. J. Biol. Chem. 1983, 258, 6282-6287. [CrossRef]

78. Moreb, J.S. Aldehyde dehydrogenase as a marker for stem cells. Curr. Stem Cell Res. Ther. 2008, 3, 237-246. [CrossRef]

79. Tomita, H.; Tanaka, K.; Tanaka, T.; Hara, A. Aldehyde dehydrogenase 1A1 in stem cells and cancer. Oncotarget 2016, 7, 11018-11032. [CrossRef]

80. Li, Y.; Chen, T.; Zhu, J.; Zhang, H.; Jiang, H.; Sun, H. High ALDH activity defines ovarian cancer stem-like cells with enhanced invasiveness and EMT progress which are responsible for tumor invasion. Biochem. Biophys. Res. Commun. 2018, 495, 1081-1088. [CrossRef]

81. Liao, J.; Qian, F.; Tchabo, N.; Mhawech-Fauceglia, P.; Beck, A.; Qian, Z.; Wang, X.; Huss, W.J.; Lele, S.B.; Morrison, C.D.; et al. Ovarian cancer spheroid cells with stem cell-like properties contribute to tumor generation, metastasis and chemotherapy resistance through hypoxia-resistant metabolism. PLoS ONE 2014, 9, e84941. [CrossRef] [PubMed]

82. Kim, D.K.; Seo, E.J.; Choi, E.J.; Lee, S.I.; Kwon, Y.W.; Jang, I.H.; Kim, S.C.; Kim, K.H.; Suh, D.S.; Seong-Jang, K.; et al. Crucial role of HMGA1 in the self-renewal and drug resistance of ovarian cancer stem cells. Exp. Mol. Med. 2016, 48, e255. [CrossRef]

83. Seo, E.J.; Kwon, Y.W.; Jang, I.H.; Kim, D.K.; Lee, S.I.; Choi, E.J.; Kim, K.H.; Suh, D.S.; Lee, J.H.; Choi, K.U.; et al. Autotaxin Regulates Maintenance of Ovarian Cancer Stem Cells through Lysophosphatidic Acid-Mediated Autocrine Mechanism. Stem Cells 2016, 34, 551-564. [CrossRef]

84. Wang, Y.C.; Yo, Y.T.; Lee, H.Y.; Liao, Y.P.; Chao, T.K.; Su, P.H.; Lai, H.C. ALDH1-bright epithelial ovarian cancer cells are associated with CD44 expression, drug resistance, and poor clinical outcome. Am. J. Pathol. 2012, 180, 1159-1169. [CrossRef] [PubMed]

85. Meng, E.; Mitra, A.; Tripathi, K.; Finan, M.A.; Scalici, J.; McClellan, S.; Madeira da Silva, L.; Reed, E.; Shevde, L.A.; Palle, K.; et al. ALDH1A1 maintains ovarian cancer stem cell-like properties by altered regulation of cell cycle checkpoint and DNA repair network signaling. PLoS ONE 2014, 9, e107142. [CrossRef]

86. Umezu-Goto, M.; Kishi, Y.; Taira, A.; Hama, K.; Dohmae, N.; Takio, K.; Yamori, T.; Mills, G.B.; Inoue, K.; Aoki, J.; et al. Autotaxin has lysophospholipase D activity leading to tumor cell growth and motility by lysophosphatidic acid production. J. Cell Biol. 2002, 158, 227-233. [CrossRef]

87. Tokumura, A.; Majima, E.; Kariya, Y.; Tominaga, K.; Kogure, K.; Yasuda, K.; Fukuzawa, K. Identification of human plasma lysophospholipase D, a lysophosphatidic acid-producing enzyme, as autotaxin, a multifunctional phosphodiesterase. J. Biol. Chem. 2002, 277, 39436-39442. [CrossRef]

88. Lee, H.Y.; Murata, J.; Clair, T.; Polymeropoulos, M.H.; Torres, R.; Manrow, R.E.; Liotta, L.A.; Stracke, M.L. Cloning, chromosomal localization, and tissue expression of autotaxin from human teratocarcinoma cells. Biochem. Biophys. Res. Commun. 1996, 218, 714-719. [CrossRef] [PubMed]

89. Sato, K.; Malchinkhuu, E.; Muraki, T.; Ishikawa, K.; Hayashi, K.; Tosaka, M.; Mochiduki, A.; Inoue, K.; Tomura, H.; Mogi, C.; et al. Identification of autotaxin as a neurite retraction-inducing factor of PC12 cells in cerebrospinal fluid and its possible sources. $J$. Neurochem. 2005, 92, 904-914. [CrossRef]

90. Wu, J.M.; Xu, Y.; Skill, N.J.; Sheng, H.; Zhao, Z.; Yu, M.; Saxena, R.; Maluccio, M.A. Autotaxin expression and its connection with the TNF-alpha-NF-kappaB axis in human hepatocellular carcinoma. Mol. Cancer 2010, 9, 71. [CrossRef] [PubMed]

91. Kishi, Y.; Okudaira, S.; Tanaka, M.; Hama, K.; Shida, D.; Kitayama, J.; Yamori, T.; Aoki, J.; Fujimaki, T.; Arai, H. Autotaxin is overexpressed in glioblastoma multiforme and contributes to cell motility of glioblastoma by converting lysophosphatidylcholine to lysophosphatidic acid. J. Biol. Chem. 2006, 281, 17492-17500. [CrossRef]

92. Nouh, M.A.; Wu, X.X.; Okazoe, H.; Tsunemori, H.; Haba, R.; Abou-Zeid, A.M.; Saleem, M.D.; Inui, M.; Sugimoto, M.; Aoki, J.; et al. Expression of autotaxin and acylglycerol kinase in prostate cancer: Association with cancer development and progression. Cancer Sci. 2009, 100, 1631-1638. [CrossRef] [PubMed] 
93. Euer, N.; Schwirzke, M.; Evtimova, V.; Burtscher, H.; Jarsch, M.; Tarin, D.; Weidle, U.H. Identification of genes associated with metastasis of mammary carcinoma in metastatic versus non-metastatic cell lines. Anticancer Res. 2002, 22, 733-740. [PubMed]

94. Altman, M.K.; Gopal, V.; Jia, W.; Yu, S.; Hall, H.; Mills, G.B.; McGinnis, A.C.; Bartlett, M.G.; Jiang, G.; Madan, D.; et al. Targeting melanoma growth and viability reveals dualistic functionality of the phosphonothionate analogue of carba cyclic phosphatidic acid. Mol. Cancer 2010, 9, 140. [CrossRef]

95. Brindley, D.N.; Lin, F.T.; Tigyi, G.J. Role of the autotaxin-lysophosphatidate axis in cancer resistance to chemotherapy and radiotherapy. Biochim. Biophys. Acta 2013, 1831, 74-85. [CrossRef] [PubMed]

96. Reya, T.; Morrison, S.J.; Clarke, M.F.; Weissman, I.L. Stem cells, cancer, and cancer stem cells. Nature 2001, 414, 105-111. [CrossRef] [PubMed]

97. Malta, T.M.; Sokolov, A.; Gentles, A.J.; Burzykowski, T.; Poisson, L.; Weinstein, J.N.; Kamińska, B.; Huelsken, J.; Omberg, L.; Gevaert, O.; et al. Machine Learning Identifies Stemness Features Associated with Oncogenic Dedifferentiation. Cell 2018, 173, 338-354.e315. [CrossRef]

98. Ben-Porath, I.; Thomson, M.W.; Carey, V.J.; Ge, R.; Bell, G.W.; Regev, A.; Weinberg, R.A. An embryonic stem cell-like gene expression signature in poorly differentiated aggressive human tumors. Nat. Genet. 2008, 40, 499-507. [CrossRef]

99. Wiechert, A.; Saygin, C.; Thiagarajan, P.S.; Rao, V.S.; Hale, J.S.; Gupta, N.; Hitomi, M.; Nagaraj, A.B.; DiFeo, A.; Lathia, J.D.; et al. Cisplatin induces stemness in ovarian cancer. Oncotarget 2016, 7, 30511-30522. [CrossRef] [PubMed]

100. Weina, K.; Utikal, J. SOX2 and cancer: Current research and its implications in the clinic. Clin. Transl. Med. 2014, 3, 19. [CrossRef] [PubMed]

101. Seo, E.J.; Kim, D.K.; Jang, I.H.; Choi, E.J.; Shin, S.H.; Lee, S.I.; Kwon, S.M.; Kim, K.H.; Suh, D.S.; Kim, J.H. Hypoxia-NOTCH1-SOX2 signaling is important for maintaining cancer stem cells in ovarian cancer. Oncotarget 2016, 7, 55624-55638. [CrossRef] [PubMed]

102. Semenza, G.L. HIF-1 mediates metabolic responses to intratumoral hypoxia and oncogenic mutations. J. Clin. Investig. 2013, 123, 3664-3671. [CrossRef] [PubMed]

103. Hayashi, Y.; Yokota, A.; Harada, H.; Huang, G. Hypoxia/pseudohypoxia-mediated activation of hypoxia-inducible factor-1 $\alpha$ in cancer. Cancer Sci. 2019, 110, 1510-1517. [CrossRef]

104. Liao, W.-L.; Lin, S.-C.; Sunny Sun, H.; Tsai, S.-J. Hypoxia-induced tumor malignancy and drug resistance: Role of microRNAs. Biomark. Genom. Med. 2014, 6, 1-11. [CrossRef]

105. Mathieu, J.; Zhang, Z.; Zhou, W.; Wang, A.J.; Heddleston, J.M.; Pinna, C.M.; Hubaud, A.; Stadler, B.; Choi, M.; Bar, M.; et al. HIF induces human embryonic stem cell markers in cancer cells. Cancer Res. 2011, 71, 4640-4652. [CrossRef] [PubMed]

106. Liang, D.; Ma, Y.; Liu, J.; Trope, C.G.; Holm, R.; Nesland, J.M.; Suo, Z. The hypoxic microenvironment upgrades stem-like properties of ovarian cancer cells. BMC Cancer 2012, 12, 201. [CrossRef]

107. Zhao, M.; Zhang, Y.; Zhang, H.; Wang, S.; Zhang, M.; Chen, X.; Wang, H.; Zeng, G.; Chen, X.; Liu, G.; et al. Hypoxia-induced cell stemness leads to drug resistance and poor prognosis in lung adenocarcinoma. Lung Cancer 2015, 87, 98-106. [CrossRef]

108. Lheureux, S.; Braunstein, M.; Oza, A.M. Epithelial ovarian cancer: Evolution of management in the era of precision medicine. $C A$ Cancer J. Clin. 2019, 69, 280-304. [CrossRef]

109. Moore, K.; Colombo, N.; Scambia, G.; Kim, B.G.; Oaknin, A.; Friedlander, M.; Lisyanskaya, A.; Floquet, A.; Leary, A.; Sonke, G.S.; et al. Maintenance Olaparib in Patients with Newly Diagnosed Advanced Ovarian Cancer. N. Engl. J. Med. 2018, 379, $2495-2505$. [CrossRef]

110. Pujade-Lauraine, E.; Ledermann, J.A.; Selle, F.; Gebski, V.; Penson, R.T.; Oza, A.M.; Korach, J.; Huzarski, T.; Poveda, A.; Pignata, S.; et al. Olaparib tablets as maintenance therapy in patients with platinum-sensitive, relapsed ovarian cancer and a BRCA1/2 mutation (SOLO2/ENGOT-Ov21): A double-blind, randomised, placebo-controlled, phase 3 trial. Lancet Oncol. 2017, 18, 1274-1284. [CrossRef]

111. Ledermann, J.A.; Pujade-Lauraine, E. Olaparib as maintenance treatment for patients with platinum-sensitive relapsed ovarian cancer. Ther. Adv. Med. Oncol. 2019, 11, 1758835919849753. [CrossRef]

112. Klotz, D.M.; Wimberger, P. Overcoming PARP inhibitor resistance in ovarian cancer: What are the most promising strategies? Arch. Gynecol. Obstet. 2020, 302, 1087-1102. [CrossRef]

113. Xia, Q.; Cai, Y.; Peng, R.; Wu, G.; Shi, Y.; Jiang, W. The CDK1 inhibitor RO3306 improves the response of BRCA-proficient breast cancer cells to PARP inhibition. Int. J. Oncol. 2014, 44, 735-744. [CrossRef] [PubMed]

114. Bellio, C.; DiGloria, C.; Foster, R.; James, K.; Konstantinopoulos, P.A.; Growdon, W.B.; Rueda, B.R. PARP Inhibition Induces Enrichment of DNA Repair-Proficient CD133 and CD117 Positive Ovarian Cancer Stem Cells. Mol. Cancer Res. MCR 2019, 17, 431-445. [CrossRef] [PubMed]

115. Kim, W.T.; Ryu, C.J. Cancer stem cell surface markers on normal stem cells. BMB Rep. 2017, 50, 285-298. [CrossRef] [PubMed]

116. Tirino, V.; Desiderio, V.; Paino, F.; De Rosa, A.; Papaccio, F.; La Noce, M.; Laino, L.; De Francesco, F.; Papaccio, G. Cancer stem cells in solid tumors: An overview and new approaches for their isolation and characterization. FASEB J. 2013, 27, 13-24. [CrossRef]

117. Xia, P. Surface markers of cancer stem cells in solid tumors. Curr. Stem Cell Res. Ther. 2014, 9, 102-111. [CrossRef]

118. Kaiser, J. The cancer stem cell gamble. Science 2015, 347, 226. [CrossRef]

119. Zhao, W.; Ji, X.; Zhang, F.; Li, L.; Ma, L. Embryonic stem cell markers. Molecules 2012, 17, 6196-6236. [CrossRef]

120. Islam, F.; Gopalan, V.; Smith, R.A.; Lam, A.K. Translational potential of cancer stem cells: A review of the detection of cancer stem cells and their roles in cancer recurrence and cancer treatment. Exp. Cell Res. 2015, 335, 135-147. [CrossRef] 
121. Kristiansen, G.; Sammar, M.; Altevogt, P. Tumour biological aspects of CD24, a mucin-like adhesion molecule. J. Mol. Histol. 2004, 35, 255-262. [CrossRef]

122. Sundberg, M.; Jansson, L.; Ketolainen, J.; Pihlajamäki, H.; Suuronen, R.; Skottman, H.; Inzunza, J.; Hovatta, O.; Narkilahti, S. $\mathrm{CD}$ marker expression profiles of human embryonic stem cells and their neural derivatives, determined using flow-cytometric analysis, reveal a novel CD marker for exclusion of pluripotent stem cells. Stem Cell Res. 2009, 2, 113-124. [CrossRef]

123. Carpenter, M.K.; Rosler, E.S.; Fisk, G.J.; Brandenberger, R.; Ares, X.; Miura, T.; Lucero, M.; Rao, M.S. Properties of four human embryonic stem cell lines maintained in a feeder-free culture system. Dev. Dyn. Off. Publ. Am. Assoc. Anat. 2004, 229, 243-258. [CrossRef] [PubMed]

124. Levin, T.G.; Powell, A.E.; Davies, P.S.; Silk, A.D.; Dismuke, A.D.; Anderson, E.C.; Swain, J.R.; Wong, M.H. Characterization of the intestinal cancer stem cell marker CD166 in the human and mouse gastrointestinal tract. Gastroenterology 2010, 139, $2072-2082$. [CrossRef]

125. Zhang, W.C.; Shyh-Chang, N.; Yang, H.; Rai, A.; Umashankar, S.; Ma, S.; Soh, B.S.; Sun, L.L.; Tai, B.C.; Nga, M.E.; et al. Glycine decarboxylase activity drives non-small cell lung cancer tumor-initiating cells and tumorigenesis. Cell 2012, 148, 259-272. [CrossRef] [PubMed]

126. Zannettino, A.C.; Paton, S.; Arthur, A.; Khor, F.; Itescu, S.; Gimble, J.M.; Gronthos, S. Multipotential human adipose-derived stromal stem cells exhibit a perivascular phenotype in vitro and in vivo. J. Cell. Physiol. 2008, 214, 413-421. [CrossRef] [PubMed]

127. Wang, F.; Scoville, D.; He, X.C.; Mahe, M.M.; Box, A.; Perry, J.M.; Smith, N.R.; Lei, N.Y.; Davies, P.S.; Fuller, M.K.; et al. Isolation and characterization of intestinal stem cells based on surface marker combinations and colony-formation assay. Gastroenterology 2013, 145, 383-395. [CrossRef]

128. Thapa, R.; Wilson, G.D. The Importance of CD44 as a Stem Cell Biomarker and Therapeutic Target in Cancer. Stem Cells Int. 2016, 2016, 2087204. [CrossRef]

129. Zöller, M. CD44: Can a cancer-initiating cell profit from an abundantly expressed molecule? Nat Rev Cancer 2011, 11, 254-267. [CrossRef]

130. Lapidot, T.; Dar, A.; Kollet, O. How do stem cells find their way home? Blood 2005, 106, 1901-1910. [CrossRef]

131. Maleki, M.; Ghanbarvand, F.; Reza Behvarz, M.; Ejtemaei, M.; Ghadirkhomi, E. Comparison of mesenchymal stem cell markers in multiple human adult stem cells. Int. J. Stem Cells 2014, 7, 118-126. [CrossRef]

132. Zuk, P.A.; Zhu, M.; Ashjian, P.; De Ugarte, D.A.; Huang, J.I.; Mizuno, H.; Alfonso, Z.C.; Fraser, J.K.; Benhaim, P.; Hedrick, M.H. Human adipose tissue is a source of multipotent stem cells. Mol. Biol. Cell 2002, 13, 4279-4295. [CrossRef]

133. Kim, J.; Woo, A.J.; Chu, J.; Snow, J.W.; Fujiwara, Y.; Kim, C.G.; Cantor, A.B.; Orkin, S.H. A Myc network accounts for similarities between embryonic stem and cancer cell transcription programs. Cell 2010, 143, 313-324. [CrossRef] [PubMed]

134. Dvorak, P.; Dvorakova, D.; Hampl, A. Fibroblast growth factor signaling in embryonic and cancer stem cells. FEBS Lett. 2006, 580, 2869-2874. [CrossRef] [PubMed]

135. Clarke, M.F.; Fuller, M. Stem cells and cancer: Two faces of eve. Cell 2006, 124, 1111-1115. [CrossRef] [PubMed]

136. Parte, S.C.; Batra, S.K.; Kakar, S.S. Characterization of stem cell and cancer stem cell populations in ovary and ovarian tumors. J. Ovarian Res. 2018, 11, 69. [CrossRef]

137. Kenda Suster, N.; Virant-Klun, I. Presence and role of stem cells in ovarian cancer. World J. Stem Cells 2019, 11, 383-397. [CrossRef]

138. Jiang, H.; Lin, X.; Liu, Y.; Gong, W.; Ma, X.; Yu, Y.; Xie, Y.; Sun, X.; Feng, Y.; Janzen, V.; et al. Transformation of epithelial ovarian cancer stemlike cells into mesenchymal lineage via EMT results in cellular heterogeneity and supports tumor engraftment. Mol. Med. 2012, 18, 1197-1208. [CrossRef] [PubMed]

139. Lau, W.M.; Teng, E.; Chong, H.S.; Lopez, K.A.; Tay, A.Y.; Salto-Tellez, M.; Shabbir, A.; So, J.B.; Chan, S.L. CD44v8-10 is a cancer-specific marker for gastric cancer stem cells. Cancer Res. 2014, 74, 2630-2641. [CrossRef] [PubMed]

140. Kemper, K.; Sprick, M.R.; de Bree, M.; Scopelliti, A.; Vermeulen, L.; Hoek, M.; Zeilstra, J.; Pals, S.T.; Mehmet, H.; Stassi, G.; et al. The AC133 epitope, but not the CD133 protein, is lost upon cancer stem cell differentiation. Cancer Res. 2010, 70, 719-729. [CrossRef]

141. Ishimoto, T.; Nagano, O.; Yae, T.; Tamada, M.; Motohara, T.; Oshima, H.; Oshima, M.; Ikeda, T.; Asaba, R.; Yagi, H.; et al. CD44 variant regulates redox status in cancer cells by stabilizing the $\mathrm{xCT}$ subunit of system $\mathrm{xc}(-)$ and thereby promotes tumor growth. Cancer Cell 2011, 19, 387-400. [CrossRef]

142. Huang, X.; Wan, J.; Leng, D.; Zhang, Y.; Yang, S. Dual-targeting nanomicelles with CD133 and CD44 aptamers for enhanced delivery of gefitinib to two populations of lung cancer-initiating cells. Exp. Ther. Med. 2020, 19, 192-204. [CrossRef]

143. Klapdor, R.; Wang, S.; Morgan, M.; Dörk, T.; Hacker, U.; Hillemanns, P.; Büning, H.; Schambach, A. Characterization of a Novel Third-Generation Anti-CD24-CAR against Ovarian Cancer. Int. J. Mol. Sci. 2019, 20, 660. [CrossRef]

144. Do, E.K.; Kim, Y.M.; Heo, S.C.; Kwon, Y.W.; Shin, S.H.; Suh, D.S.; Kim, K.H.; Yoon, M.S.; Kim, J.H. Lysophosphatidic acid-induced ADAM12 expression mediates human adipose tissue-derived mesenchymal stem cell-stimulated tumor growth. Int. J. Biochem. Cell Biol. 2012, 44, 2069-2076. [CrossRef] [PubMed]

145. Heo, S.C.; Lee, K.O.; Shin, S.H.; Kwon, Y.W.; Kim, Y.M.; Lee, C.H.; Kim, Y.D.; Lee, M.K.; Yoon, M.S.; Kim, J.H. Periostin mediates human adipose tissue-derived mesenchymal stem cell-stimulated tumor growth in a xenograft lung adenocarcinoma model. Biochim. Biophys. Acta 2011, 1813, 2061-2070. [CrossRef] [PubMed] 
146. Jeon, E.S.; Moon, H.J.; Lee, M.J.; Song, H.Y.; Kim, Y.M.; Cho, M.; Suh, D.S.; Yoon, M.S.; Chang, C.L.; Jung, J.S.; et al. Cancer-derived lysophosphatidic acid stimulates differentiation of human mesenchymal stem cells to myofibroblast-like cells. Stem Cells 2008, 26, 789-797. [CrossRef]

147. Lee, M.J.; Jeon, E.S.; Lee, J.S.; Cho, M.; Suh, D.S.; Chang, C.L.; Kim, J.H. Lysophosphatidic acid in malignant ascites stimulates migration of human mesenchymal stem cells. J. Cell. Biochem. 2008, 104, 499-510. [CrossRef] [PubMed]

148. Kim, E.K.; Yun, S.J.; Do, K.H.; Kim, M.S.; Cho, M.; Suh, D.S.; Kim, C.D.; Kim, J.H.; Birnbaum, M.J.; Bae, S.S. Lysophosphatidic acid induces cell migration through the selective activation of Akt1. Exp. Mol. Med. 2008, 40, 445-452. [CrossRef]

149. Mo, W.M.; Kwon, Y.W.; Jang, I.H.; Choi, E.J.; Kwon, S.M.; Kim, J.H. Role of TAZ in Lysophosphatidic Acid-Induced Migration and Proliferation of Human Adipose-Derived Mesenchymal Stem Cells. Biomol. Ther. 2017, 25, 354-361. [CrossRef] [PubMed]

150. Raghavan, S.; Snyder, C.S.; Wang, A.; McLean, K.; Zamarin, D.; Buckanovich, R.J.; Mehta, G. Carcinoma-Associated Mesenchymal Stem Cells Promote Chemoresistance in Ovarian Cancer Stem Cells via PDGF Signaling. Cancers 2020, 12, 2063. [CrossRef] 